Available online:

http://journal.imla.or.id/index.php/arabi

IMLA

Arabi : Journal of Arabic Studies, 4 (1), 2019, 1-10

DOI: http://dx.doi.org/10.24865/ajas.v4i1.147

\title{
PHONOLOGICAL DIMENSION OF THE ARABIC WORDS: THE INTIMATE RELATION BETWEEN SOUND AND MEANING IN THE ARABIC WORDS
}

\author{
Achmad Khusnul Khitam
}

Sekolah Tinggi Agama Islam Sunan Pandanaran Yogyakarta, Indonesia

E-mail : khitammaliki@gmail.com

\begin{abstract}
This research aims to discover the relation between sound and meaning in the Arabic words. Sound, as the smallest contrastive linguistic unit has a huge influence on bringing change of meaning. The preference of certain phoneme on a word may produce certain meaning inside it. Therefore, a singel word with different phonemes produces different meaning. This research based on library research, a research proceed by gathering some facts from various books, articles, and other literatures related to the subject. This research combines semantical approach and phonological approach with analytic description method. From this research, it is found that Arabic words use certain phoneme to express certain meaning; phoneme with heavy articulation oftenly uses to express heavy activity, and phonems with light articulation oftenly uses to express light acivity.
\end{abstract}

Keywords: Arabic words, Sound, Meaning, Phonology

\section{Abstrak}

Riset ini bertujuan untuk mengungkap hubungan antara bunyi dan makna dalam kosa kata bahasa Arab. Bunyi, sebagai unit terkecil dalam bahasa memilliki pengaruh yang besar dalam memberikan perubahan pada makna. Dalam hal ini, pemilihan fonem tertentu dalam sebuah kosa kata dapat memunculkan makna tertentu di dalamnya. Artinya, sebuah kosa kata dengan variasi fonem yang berbeda dapat memunculkan makna yang berbeda pula. Riset ini merupakan Library research (riset kepustakaan), yang dilakukan dengan mengumpulkan beberapa fakta dari berbagai buku, artikel, dan beberapa literatur lain yang terkait dengan topik pembahasan. Riset ini mengkombinasikan antara pendekatan semantik dan fonologis disertai dengan metode deskriptif analitis. Dari riset ini ditemukan bahwa kosa kata dalam bahasa Arab cenderung menggunakan fonem tertentu untuk mengungkapkan makna tertentu; fonem yang memiliki artikulasi yang berat sering digunakan untuk mengungkapkan makna atau aktivitas yang berat, begitu juga fonem yang memiliki artikulasi yang ringan sering digunakan untuk makna atau aktivitas yang ringan.

Kata Kunci: Kosa Kata Bahasa Arab, Bunyi, Makna, Fonologi 


\section{Arabi : Journal of Arabic Studies}

\section{Introduction}

In the study of language, one of the main purposes in developing various linguistic theories is to simply deliver meanings (Burling, 2015: 138-162). Given the fact that language is the main code used by human to express their ideas (Berlo, 1960: 1), it is important to be underlined that the understanding the structural forms which contain ideas is a vital. That is because to deliver ideas, the speaker would string up some words and sentences, and develop them in a sequence of structural forms which usually pursue linguistic norms where the communication takes place.

In the Arabic world, the formation of Arabic linguistics had been formally conducted by making a standardization of al-lugah al-'Arabiyyah al-fushā mainly to prevent the spread of allahn (Daif, 1968: 11). In one hand, this effort would be beneficial for the Arab in term of organizing their language, but on the other hand, this might also falsify some language's utterances or sentences that were not included in the standardization and in return, would omit meanings that might exist in those units (Hachimi, A., 2015: 35-70). This means that all of the expressions of ideas or meanings should be standardized by putting them into grammatical norms (Naumkin V, 2016: 19-60). Of course, there would not be a problem if those ideas could perfectly fit in grammatical norms, meaning that there are no other factors which may relate to meaning's determination. But what if, for instance, the idea could only be expressed verbally because some other factors? What if the preference of certain sounds apparently has an intimate relation to meaning rather than merely grammatical norms?

Certainly, it should not be a problem if the communication goes verbally because the speaker always has the opportunity to utilize sound features. However, it would go oppositely if the communication exists in textual form where the reader could only see the text (Amor, 2013: 1523). That is why, understanding the possibility of this sounds' preference which may exist within the text is also a vital to understand the whole meanings. Otherwise, the ideas which the speaker (or writer) wanted to deliver would be undelivered (McDowell, 2012: 169-178).

At this point, there is an important thing in which the ideas can be successfully delivered through communication, which is sound. The existence of sound reflects how the speaker or writer prefers sequences of sounds before string them up and develop them into a complete meaningful sentence (Ruddell, 1966: 489-498). In fact, sounds have their specific and distinctive characters which may differentiate one from another (Goldsmith, 2009: 4-38). In the case of Arabic language, these unique and distinctive characters, according to some Arabic linguists, apparently have a kind of relation to determine a specific meaning as they are usually preferred by the native speakers in their words and sentences to express specific meanings in specific contexts (Nahr, 2007: 49).

From those brief descriptions, we can be assured that there is an intimate relation between sound and meaning in the Arabic language, which also means the involvement of sound on determining specific meaning as used by the Arabs. Based on this phenomenon, this article tries to elaborate the phonological dimension of Arabic language, especially in words' level. To conduct the analysis, I would like to use two approaches respectively, phonological and semantic approaches; the first one is used to understand the characters of Arabic sounds including their preference among others, while the second one is used to know the relationship between sound and meaning. By using both approaches and combine them with an analysis of related contexts, I sincerely hope that this article would comprehensively describes the phenomenon of the Arabic sound and meaning relation.

\section{Method}

This research was considered as a library research, which was proceed by collecting several data from related books, articles, or any other references related to the subject. Regarding this, the prime source of this research would be Arabic dictionaries, whereas the secondary sources would be some related books which discuss phonetics ('ilm al-ashwät), phonology (ad-dalālah ashshautiyyah), and semantics ('ilm ad-dalālah). 
This research used phonological and semantics approaches. The first was used to understand the characters of each sound occur in words or sentences, mainly from its three main characters in order to understand the difference of their sounds, namely the position of soundtrack, the place of articulation, and the way of articulation. The second approach was used, firstly to analyze the influence of sound to meaning, and secondly to discover those implicit meanings which are related to their sounds and their specific contexts.

In order to give solution to the problems systematically, the collected data were proceed in following steps: 1) collection; searching the data, namely all of the Arabic words which are indicated semantically and phonologically to have a relation between sound and its meaning, 2) classification; classifying those data based on some particular cases, 3) analysis; analyzing the data by using phonological and semantic approaches to each cases.

\section{Result and Discussion \\ Phonemic System of Arabic: Identification and Classification}

Arabic phonemes, as occur in any existing language, consist of vowels and consonants. The difference between both can be found technically in the phonetic process; vowel phonemes do not get any closures when the air passes through sound track, while consonant phonemes get it (Crystal, 2008: 517, 103). Another difference can also be found in the actual number of those phonemes (Shariq, 2015: 146-152). Ali al-Khūli for instance, states that the total number of Arabic phonemes are 34 which comprise 28 consonants and 6 vowels al-Khūli, 1982: 37), whereas Ramụān 'Abd at-Tawwāb counts there are 39 Arabic phonemes in total with 33 consonants -by adding phonemes /b/, /z/, /q/, and /r/ from various Arabic dialects- and 6 vowels (at-Tawwāb, 1985: 24). Nasr himself has a notion that the numbers of Arabic phonemes are 36 in total with 30 consonants -by differentiating between phonemes /1/ and /r/ which are pronounced by tafkhim and tarqi $q$ - and 6 vowels (Nasr, 1967: 19-45.)

Based on these distinctive opinions, the difference concerning this identification only occurs in the number of consonants. Regarding this, in my opinion, Khūli's identification which states that the numbers of Arabic consonants are 28 is contextually representable. That is because four additional phonemes added by at-Tawwāb are specific phonemes which exclusively used in specific dialects; while the differentiation of tafkhìm and tarqī $q$ in phonemes $/ 1 /$ and $/ \mathrm{r} /$ are merely occur in variety of pronunciations which are basically based on the same phonemes. Finally, all of those 28 consonant phonemes of the Arabic are: l/l/, ب/b/, ت/t/,

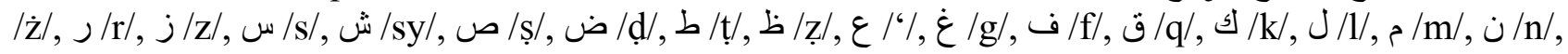
$\bullet / \mathrm{h} /$, , و/w/, and $/ \mathrm{y} /$. Whereas 6 vowel phonemes are those occur as harakät in Arabic sound system, which are short and long fathah $(/ \mathrm{a} /$ and $/ \overline{\mathrm{a}} /)$, short and long dhammah $(/ \mathrm{u} / \mathrm{and} / \overline{\mathrm{u}} /)$, and short and long $\mathrm{kasrah}(/ \mathrm{i} /$ and $/ \mathbf{1} /)$.

Regarding the classification of Arabic phoneme, consonants are usually differentiated by three main categories, namely position of sound track, place of articulation, and way of articulation (Chaer, 2007: 116). Based on position of sound track, consonants are divided into two types of sounds, which are voiced sounds (al-ashwät al-majhürah) consisting l/l/, ب/b/, ج/j/, د/d/,

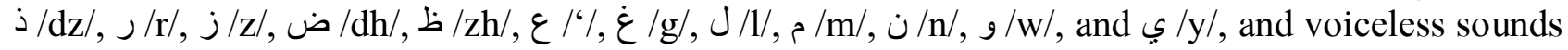

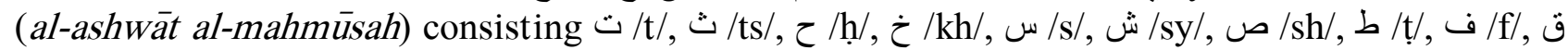
/q/, s] $/ \mathrm{k} /, \circ / \mathrm{h} /$.

The second and third categories i.e. the place of articulation and the way of articulation have been separately discussed in many linguistic works (Alotaibi, 2013: 1426-1439). Thus, in order to simplify the classification, in this article I would put the classification that is found as well as described in those works into one single table in order to simplify the reading as well as understanding concerning this issue as follows: 
Arabi : Journal of Arabic Studies

\begin{tabular}{|c|c|c|c|c|c|c|}
\hline $\begin{array}{l}\qquad \begin{array}{l}\text { Way of } \\
\text { Articulation }\end{array} \\
\text { Place of } \\
\text { Articulation }\end{array}$ & 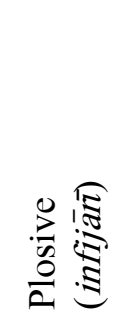 & 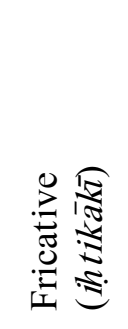 & $\begin{array}{l}\text { 急 } \\
\text { ż }\end{array}$ & 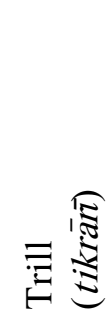 & 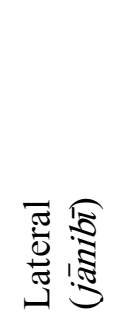 & 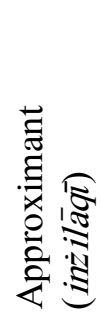 \\
\hline $\begin{array}{l}\text { Bilabial } \\
\text { (syafawiyyah) }\end{array}$ & ب/b/ & & $\rho / \mathrm{m} /$ & & & g/w/ \\
\hline $\begin{array}{l}\text { Labiodental } \\
\text { (atsnāniyyah syafawiyyah) }\end{array}$ & & /f/f/ف & & & & \\
\hline $\begin{array}{l}\text { Apico-interdental } \\
\text { (dzalqiyyah bainaal- } \\
\text { atsnann) }\end{array}$ & & $\begin{array}{l}\text { ظ/zh/ } \\
\text { ذ/dz/ } \\
\text { ث/ts/ }\end{array}$ & & & & \\
\hline $\begin{array}{l}\text { Apico-dental } \\
\text { (atsnāniyyah żalqiyyah) }\end{array}$ & $\begin{array}{l}\text { b/th/ } \\
د / d / \\
ت / t / \\
ض / d h /\end{array}$ & & & & & \\
\hline $\begin{array}{l}\text { Apiko-alveloar } \\
\text { (lasawiyyah żalqiyyah) }\end{array}$ & & $\begin{array}{l}\text { j/z/ } \\
ص / s h / \\
س / s /\end{array}$ & & & & \\
\hline $\begin{array}{l}\text { Apiko-palatal } \\
\text { (dzalqiyyah hanakiyyah) }\end{array}$ & & & ن/n/n ن & ر/r/ & J/1/ & \\
\hline $\begin{array}{l}\text { Medio-palatal } \\
\text { (wasthal-hanak) }\end{array}$ & 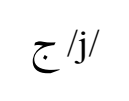 & ش/sy/ & & & & ي/y/ \\
\hline $\begin{array}{l}\text { Darsovelar } \\
\text { (aqsāal-hanak) }\end{array}$ & ك/k/ & & & & & \\
\hline $\begin{array}{l}\text { Uvular } \\
\text { (lahwiyyah) }\end{array}$ & ق/q/ & & & & & \\
\hline $\begin{array}{l}\text { Phre-pharyngeal } \\
\text { (adna al-halaq) }\end{array}$ & & $\begin{array}{l}\dot{\varepsilon}^{/ \mathrm{gh} /} \\
\dot{\tau}^{/ \mathrm{kh} /}\end{array}$ & & & & \\
\hline $\begin{array}{l}\text { Pharyngeal } \\
\text { (awsāth al-halaq) }\end{array}$ & & $\begin{array}{l}\varepsilon^{/ \%} \\
\tau^{/ \mathrm{h} /}\end{array}$ & & & & \\
\hline
\end{tabular}




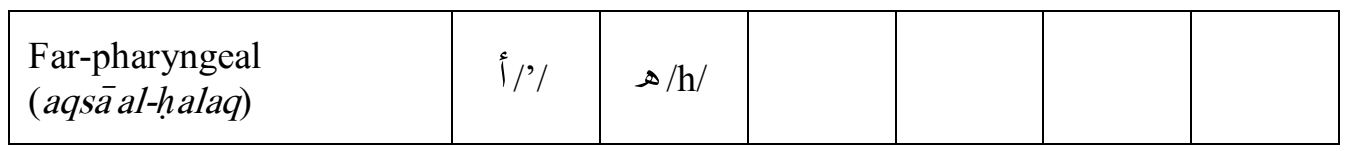

Table 1. the place of articulation and the way of articulation

In addition to those three classifications, Arabic consonants are also divided into two more categories, namely closed consonants (al-ithbäq) and open consonants (al-infitah) (al-Khūli, 1982: 19, 25). Closed consonants are produced when the tongue moves close to the gums in the middle of phonetic process, and it contains phonemes ص/sh/, ض//dh/, ط/th/, and b/zh/. On the other hand, open consonants are produced when the tongue does not move close to the gums in the

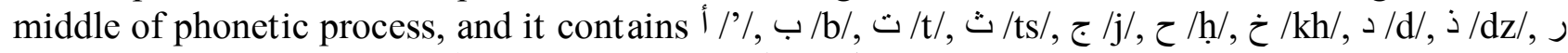

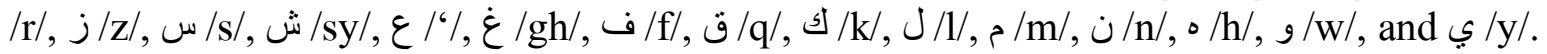

\section{The Inception of Arabic Phonology}

The study of sound and meaning in the Arabic tradition had commenced in the classical period of Islam (Zlatic, 2012: 159-169), as many prominent ushüliyyūn, baläghiyyūn, and lughawiyyün attempted to elaborate the relation between language of the Qur' an and its meaning in order to grasp some principles, especially in Islamic laws and linguistics (Nahr, 2007: 49). In this regard, they focused the study on the harmonization as well as deviation of the language of Qur'an which were structurally irregular in the Arabic perspective. This phonological study has been developed then by some Muslim scholars as well as linguists by making a comprehensive elaboration as written within their books, some of which were Al-Khalīl bin Aḥmad al-Farāhīdī, Sibawaih, and Ibn Jinni.

Interestingly, all of these three prominent figures in Arabic linguistic tradition asserted that in the Arabic language, there is an intimate relation between sounds that is used in the structure and meaning which occurs behind those structures. In order to strengthen this argument, they provided dozens of Arabic words whose sounds preferences were based on the references occurred in real events; heavy sounds were chosen in words that referred to heavy meanings or hard activities, whereas soft sounds were chosen in words that referred to soft meanings or light activities (Jinni, 1999: 165). For instance, there are words like قضم which consists of phonemes /qa/ /dhi/ and /ma/ and خضم consists of phonemes / kha/ /dhi//ma/. The difference between the first and the second occurs only in the first phonemes, which are /qa/ in the first word and / kha/ in the second. Semantically, both words generally mean to 'to chew', however, there is still a difference in the usage for both words; the first word has been used to chew something hard, while the second to chew something soft. This difference apparently relates to the characteristic of both phonemes occur in both words. The articulation of phoneme /qa/ in qadhima is harder than the articulation of phoneme $/ \mathrm{kha} /$ in khadhima. That is why the first word means to chew something hard while the second means to chew something soft (Anis, 1999: 73-74).

In the following period, phonology, either in Arabic or Western tradition, had been rolled under semantic study as the main roof, as it covered almost all units in language level, including phonological semantic as its sub-discipline which exclusively discusses meaning that is based on sound (Yule, 2010: 42-43). In Arabic tradition, the term of ad-Dalālah ash-Shautiyyah has been commonly used to address such matter. It is actually a combination of two terms which concern two respective fields of study, namely ' $I l m$ ad-Dalälah (semantics) which deals with meanings, and 'Ilm al-Ashwät (phonology) which specifically discusses sounds.

At this point, the study of sound is basically divided into two distinctive sub-disciplines, one of which is related to meaning, which is Phonology (ad-Dalalah ash-Shautiyyah) and the other is merely discussed sound physically and not related to meaning, which is Phonetics ('Ilm alAshwāt). However, one thing that should be understood is that the study of sounds which is related to meaning is also discussed under another sub-discipline in linguistics, namely semantics. This means that "phonology," to some extent, actually stands in two fields of linguistic study at 


\section{Arabi : Journal of Arabic Studies}

the same time; one in phonology, another in semantics. Even though, in linguistic study, this matter has been usually discussed in semantic study since it mainly discusses meaning.

Numbers of linguists give their various definitions concerning this term. Ibrāhim Anīs (Anīs, 1958: 46), for instance, defines semantic phonology as a part of semantic study that is grounded in the character of sounds as its basis, whereas Farīd Haidar (Haidar, 2005: 30) states that semantic phonology is merely a part of semantics which studies on sound's meaning, including the changes of meanings as the consequences of the change of sounds. Thus, based on these two definitions, I come to a conclusion that semantic phonology is a part of linguistic sub-disciplines which concerns specifically on and discusses phonemic sounds occur in linguistic words or sentences and how those sounds can give an effect on meaning. This practically means that if a tiny part of a certain sound of single word changes, for instance, then the whole meaning of this word -let alone the whole structures- could change either.

\section{Arabic Phonology: Theoretical Findings}

Theories concerning this field of studies have been produced since the classical period of the Arabic tradition. One of those prominent linguist who concern about this issue was Ibn Jinni. In this case, he was the one who identified that dalalah shautiyyah (phonological semantics) could be generalized into two major parts, namely dalälah shautiyyah thabī'iyyah (natural phonological semantics) and dalālah shautiyyah tahliliyyah (analytical phonological semantics) (Jinni, 1999: 152). The first part discusses sounds natural sounds which are grasped and adopted into linguistic words, such as the word of "غاق" (crow) in Arabic is basically adopted from the sound of the crow itself. This kind of language phenomenon has been defined by linguists after then as the phenomenon of Onomatopoeia. On the other hand, the second part discusses phonemic sounds which exist in any linguistic levels, either segmentally or supra-segmentally. Thus, most of the study of sounds and their relation to meanings are contained within this part.

Regarding this, Ibn Jinni has described those sub divisions sporadically within his book, alKhashaish mostly by delivering some Arabic words and sentences which could support his arguments. However, in my opinion, this elaboration actually could be systematized and turned into a phonological theory that could be applied in any language. In summary, Ibn Jinni's elaboration firstly depart from dalālah shautiyyah which consists of dalālah shautiyyah thabì 'iyyah and dalālah șautiyyah tahliliyyah; whereas dalālah shautiyyah taḥliliyyah consists of dalālah shautiyyah tarkïbiyyah (segmental phoneme) and dalālah shautiyyah ghair tarkibiyyah (suprasegmental phoneme). All of these theoretical findings on Arabic phonology basically can be systematized in the following chart:

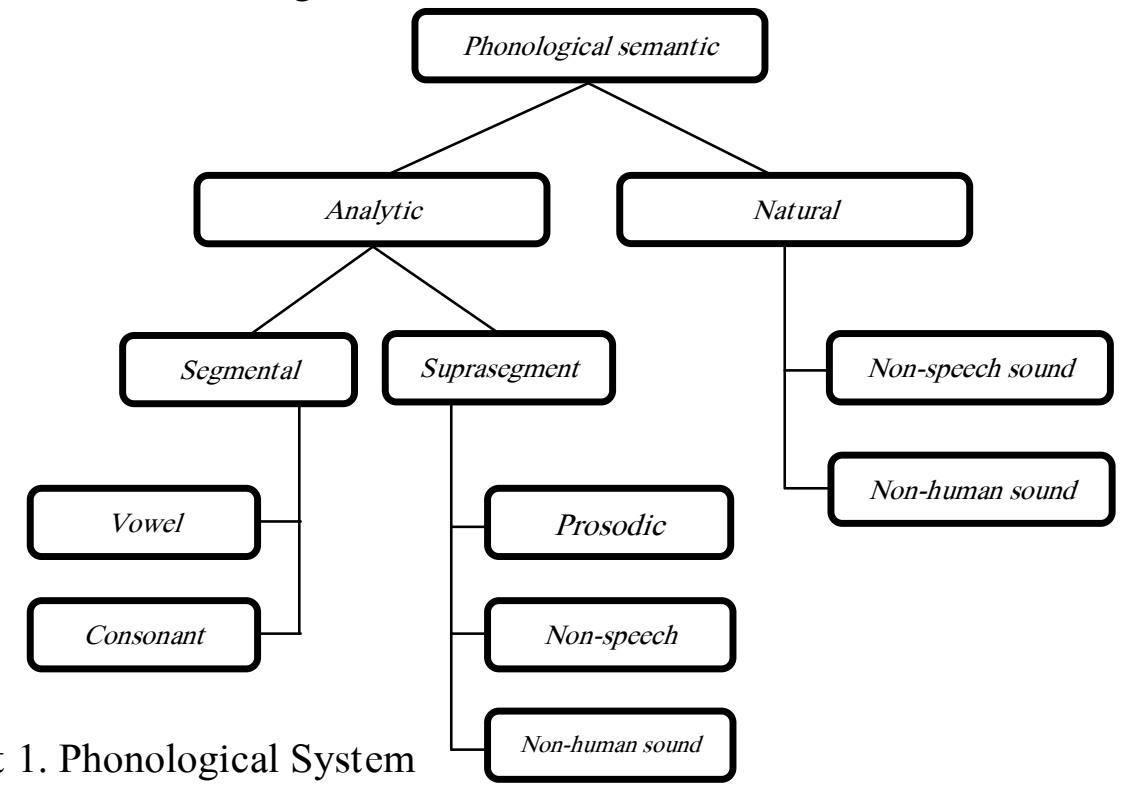

Vol. 4 No. $1 \mid 6-10$

Copyright @ 2019 | ARABI | p-ISSN 2548-6616 | e-ISSN 2548-6624 
Although there are dozens of theoretical part which can be elaborated as well as analyzed, however, due to limited opportunity, in this article, I only focus on segmental phoneme of Arabic, since, as far as I concern, it occurs multiply in Arabic words and sentences. Thus, in this occasion, I would use Jinni's theory specifically in dalālah shautiyyah tarkïbiyyah (segmental phoneme) and attempt to use it as a tool to analyze the subject i.e. some cases in Arabic words and subsequently to discover the influence of it phonemic sounds on determining meaning.

\section{Cases on the Relation between Sound and Meaning in the Arabic Words}

After conducting data's inventory from Arabic words, I have found several cases which indicate that there is an intimate relation between the preference of sound and meaning in those words. In this regard, I have found that meanings which are contained in the texts are strongly related to the characteristics of certain phonemes occur in within the text, such as the place or articulation (al-makhraj), way of articulation (an-nuthq) or other phonemes' characteristics.

In the first case, there is the word "صعد" in the Arabic which comprises phonemes /sh/, /a/, /\%,/a/, /d/, and /a/ with the word "wعد" which comprises phonemes /s/, /a/, /\%/, /a/, /d/, and /a/. The difference between both words occurs in their first phonemes, which are phonemes $/ \mathrm{s} /$ in the first word and phoneme /s/ in the second word. From the place of articulation (al-makhraj), both phonemes were phonologically apicoalveloar whose sound is produced when the tongue moves close to hard palate. And from the way of articulation, both of those words are fricative which means that the sound of both phonemes is produced when the active articulator moves close to the passive articulator and only leaves a tiny gap for the air to get through it without any closure.

Although both phonemes are similar in their place of articulation and the way of articulation, however, both of these phonemes do not share similar characteristic in another point of view; phoneme /ș/ in the first word is a closed phoneme (al-ithbāq); the tongue dose move close to the gum when the sound is produced, whereas phoneme /s/ is an open phoneme (al-infitah); the tongue dose not move close to the gum when the sound is produced.

From these phonological facts, I have found that the similarity (in the place of articulation and the way or articulation) and difference (in open phoneme and closed phoneme) between both words have a close relation to their specific meanings. Both words generally have a similar element of meaning "الاستعلاء" or "transcendence" as they also have a similar place of articulation which is apicoalveloar and way of articulation which is fricative. The difference is that the first word "صعد" which consists of phoneme /ṣ/ is originally used in concrete context, including

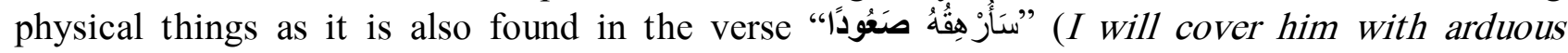
torment) (Q.S. al-Mudatstsir (74): 17).

On the other hand, the word "سعد", is usually used in the opposite context, which is an abstract context. The Arab has been used this word to this type of specific meaning as it is found in their expression, such as "رجل سعيد الجد أي عالي الجد" (Ibn Fāris, 1979: 384) or "someone who has high sincerity."

The difference of these specific elements of both meanings is also in line with the difference of their distinctive characteristics; the articulation of phoneme /s/ which is a closed phoneme is phonetically harder than the articulation of phoneme /s/ which is an open phoneme. That is why, the word "صعد" in the verses of Qur' an is used in a concrete context or situation, whereas the word "سعد" in general Arabic language is used in abstract context, because concrete meaning is stronger than abstract meaning (ad-dalālah al-lafzhiyyah aqwā min ad-dalālah al-ma'nawiyyah)

Another case has been found in the word "قi" in the Arabic language which comprises phonemes /f/, /a/, /t/, /a/, /h/, and /a/ with the word "فضح" which comprises phonemes /f/, /a/, /dh/, $/ \mathrm{a} /, / \mathrm{h} /$, and $/ \mathrm{a} /$. The difference between both words only occurs in their middle phonemes, which are phonemes $/ \mathrm{t} /$ in the first word and phoneme $/ \mathrm{dh} /$ in the second word. If we look from the place of articulation, both phonemes were phonologically apicodental whose sound is produced when the 


\section{Arabi : Journal of Arabic Studies}

tip of tongue moves close to upper teeth. And from the way of articulation, both of those words are plosive.

Although both phonemes are similar in their place of articulation and the way of articulation, however, if we look it from another characteristic of both phonemes, we would see that they do not share similar characteristic; phoneme /t/ in the first word is an open phoneme (alinfitāh), whereas phoneme /dh/ is a closed phoneme (al-ithbāq).

From these phonological facts, I have found that the similarity (in the place of articulation and the way or articulation) and difference (in open phoneme and closed phoneme) between both words which consist of both phonemes have a close relation to their specific meanings. Generally, both words have a similar element of meaning "الانكثاف" or a "disclosure" as they also have a similar place of articulation which is apicodental and way of articulation which is plosive. The difference is that the first word "فتح" which consists of phoneme /t/ is originally used in the

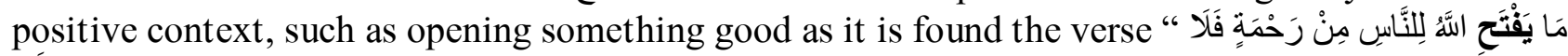
"مَمِسكَكَ لَهَا " Whatever Allah grants to people of mercy-none can withhold it) (Q.S. Fātịir (35): 1-2).

In other hand, the word "فضح" which consists of phoneme /dh/ is usually used in the context of opening something evil, bad, or other negative situations. This specific meaning has been used by the Arabs as they usually express "افتضح الرجل" to call someone whose notoriety has been exposed (Ibn Fāris, 1979: 509). The difference of these specific elements of both meanings is apparently in line with the difference of their distinctive characteristics. In this case, the articulation of phoneme $/ \mathrm{dh} /$ which is a closed phoneme is phonetically harder than the articulation of phoneme /t/ which is an open phoneme. That is why, the word "فتح" in the verses of Qur' an is used in positive contexts, whereas the word "فضح" in general Arabic language is used in negative contexts, because the exposure of something bad or evil would usually give harder and serious impacts rather than the exposure of something good.

In addition to the case, I also found the word "قصم" which comprises phonemes /q/, /a/, /sh/, /a/, /m/, and /a/ with the word "قنم" which comprises phonemes /q/, /a/, /s/, /a/, /m/, and /a/. As we can see that the difference between both words only occurs in their middle phonemes, which are phonemes $/ \mathrm{sh} /$ in the first word and phoneme $/ \mathrm{s} /$ in the second word. If we look from the place of articulation (al-makhraj), both phonemes were phonologically apicoalveloar, whereas from the way of articulation, both of those words are fricative.

Although both phonemes are similar in their place of articulation and the way of articulation, however, from another characteristic of both phonemes, we would see that they do not share similar characteristic; phoneme /ṣ/ in the first word is a closed phoneme (al-ithbāq), whereas phoneme /s/ is an open phoneme (al-infitah).

From these phonological characteristics, I have found that the similarity (in the place of articulation and the way or articulation) and difference (in open phoneme and closed phoneme) between both words which consist of both phonemes have a close relation to their specific meanings. Generally, both words have a similar element of meaning "التفريق" or "separation" as they also have a similar place of articulation which is apicoalveloar and way of articulation which is fricative. However, I have also found that there is a slight different between both words in term of their specific meanings; the first word "قصم" which comprises of phoneme /s / also consists of the specific meaning of "الكسر" or "break" (Ibn Fāris, 1979: 93). That is why this word consists of

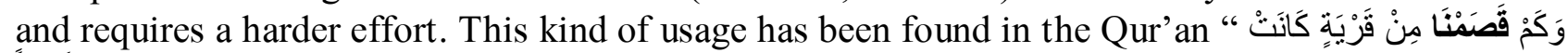
"ظَالِلَةًَ" (And how many a city which was unjust have We shattered) (Q.S. al-Anbiyā' (21): 10-11).

On the other hand, the word "قسم", despite of its original meaning, it also consists of specific meaning, which is "تجزئة الثيء" or "distributing something" (Ibn Fāris, 1979: 86) which -in this case- certainly does not requires effort as much as in the previous word, for instance in the Arabic sentence "قسمتُ المقالة للمؤتمر (I have distributed the article for the conference).

The difference between these specific elements of both meanings perfectly matches with the difference of their distinctive characteristics; the articulation of phoneme /s / which is a closed 
phoneme is phonetically harder than the articulation of phoneme /s/ which is an open phoneme. That is why, the word "قصم" is used in a harder activity, whereas the word "قسم" is not. That is because to split and break something into pieces is actually harder and requires efforts than merely to distribute something.

\section{Conclusion}

Based on previous description concerning this issue, we would agree that the Arab tend to use certain phoneme (sound) in order to express certain meaning. Regarding this, I have found that the distinctive phonemes which may differentiate between several words (as minimum pair) either occur in place of articulation, way of articulation, or other characters. I also have found that meaning of Arabic word is strongly influenced by the preference of its phonemes (sounds). Meaning that the preference of certain characters which may occur in a word is deliberately used to point out certain meaning, which means that, for instance, a closed sound which occurs in a word, is usually used to point out a hard and serious meaning, while an open sound which occurs in a word is used to point out lighter and calm meaning.

However, those findings, in my opinion, may not be accepted as a scientifically stable and verified theory yet as not many scholars, particularly linguists who urge to do a research in this field as a tool to analyze some subjects. There are also some lacks or weaknesses -which hopefully would be solved by some researchers in the near future- within this theory, one of which is concerning the standardization of determining minimum pair in some words which their distinctive phonemes could be encountered one to another. Nevertheless, it should be unquestionable to point out that this hypothesis concerning this issue has been considered as beneficial contribution toward Islamic studies, or Arabic studies in particular as some researchers have used it as a tool in their researches.[]

\section{References}

Abd at-Tawwāb, Ramḍān. 1985. al-Madkhal ilā 'Ilm al-Lugah wa al-Manāhij al-Lugawī. Cairo: Maktabah al-Khanji.

Alotaibi, Yousef. 2013. "Review of Distinctive Phonetic Feature and the Arabic Share in Related Modern Research”, Journal of Electrical Engineering \& Computer Science, Vol. 21.

Amor, Mohamed. 2013. "The Role of Arabic Orthographic Literacy in the Phonological Awarness of Tunisian Children", Journal on New Trends in Educational and Their Implication, Vol. 4, No. 2.

Anis, Ibrahim. 1999. al-Ashwāt al-Lugawiyyah. Cairo: Maktabah al-Angelo al-Mishriyyah.

Anis, Ibrahim. 1958. Dalālah al-Alfãz. Cairo: Maktabah al-Angelo al-Mishriyyah.

Berlo, David K. 1960. The Process of Communication: An Introduction to Theory and Practice. USA: Rinehart and Winston Inc.

Burling, Robbins. 2015. "The Role of Meaning in the Study of Language: A Defence of Reference", Journal Word, Vol. 22.

Chaer, Abdul. 2007. Linguistik Umum. Jakarta: Rineka Cipta.

Crystal, David. 2008. A Dictionary of Linguistics and Phonetics. UK: Blackwell Publishing.

Dhaif, Syauqi. 1968. al-Madāris an-Nahwiyyah. Cairo: Dār al-Ma’arif.

Fāris, Aḥmad ibn. 1979. Mu’jam Maqāyis al-Lugah. Beirut: Dār al-Fikr.

Goldsmith, John. and Aris Xanthos. 2009. “Learning Phonological Categories”, Journal Language, Vol. 85, No. 1. 
Arabi : Journal of Arabic Studies

Hachimi, A. 2015. Good Arabic, Bad Arabic" Mapping Language Ideologies in the Arabicspeaking World", Journal of Arabic Linguistics 61.

Haidar, Farīd 'Awid. 2005. 'Ilm ad-Dalālah: Dirāsah Nazhariyyah wa Tathbìqiyyah. Cairo: Maktabah al-Adab.

Jinni, Uṡmān ibn. 1999. al-Khashāish. Egypt: al-Hai'ah al-Mishriyyah al-‘Āmmah li al-Kitāb.

al-Khūlī, 'Alī. 1982. Mu'jam 'Ilm al-Ashwät. Riyad: n.p.

McDowell, Paula. 2012. "Ong and the Concept of Orality", Religion and Literature, Vol. 44, No. 2.

Nahr, Hādi. 2007. 'Ilm ad-Dalālah at-Tathbīqi fi at-Turāts al-'Arabỉ. Jordan: Erbid.

Nasr, Raja. 1967. The Structure of Arabic from Sound to Sentence. Beirut: Librarie du Libnan.

Naumkin, V., et.al. 2016. "Studies in the Verbal Morphology of Soqotri", Journal of Arabic Linguistics, No. 63.

Ruddell, Robert B. 1966. "Oral Language Skills and the Development of Other Language Skills", Elementary English, Vol. 43, No. 5.

Shariq, Mohammed. 2015. "Arabic and English Consonants: A Phonetic and Phonological Investigation", Advances in Language and Literary Studies, Vol. 6, No. 6.

Zlatic, Thomas D. 2012. "Talking Literature and Religion: Walter Ong", Religion and Literature, Vol. 44, No. 2. 